\title{
Distribution of Burden of Criminal Proof
}

\author{
Changlin $\mathrm{Ke}$ \\ The Department of Justice \\ Human Judicial Police Vocational Collage \\ Changsha, China
}

\begin{abstract}
The distribution of burden of criminal proof shall follow following principles: burden of proof borne by claimant, litigation efficiency, objection of forcing self-incrimination and presumption of innocence. In the juridical practice, because the accusing party desires for the litigation efficiency excessively and the relevant responsibility is unclear, many unjust, false and erroneous cases are produced by inducement leading to confession and extortive confession, which will cause the difficult implementation of distribution system of burden of criminal proof and difficult guarantee of equality between accusation and defense. Therefore, we shall improve the idea of scientific burden of proof in the construction system, the guarantee of defendant's related rights, reform of procuratorial system and other aspects.
\end{abstract}

Keywords-distribution principle; presumption of innocence; burden of proof; system improvement

\section{INTRODUCTION}

It is explicitly stipulated in the Criminal Procedure Law that the public prosecution organ or private prosecutor shall bear the burden of proof that affirm the defendant is guilty, which means the defendant and the defender bear no burden of proof that prove whether the defendant is guilty. In fact, as the special subject bearing the burden of proof sill shall bear the responsibility of affording proof, but the burden on the defendant shall not be increased because of this. The accusing party often affords incomplete proof without due diligence in the juridical practice. Some suggestions for distribution of burden of criminal proof are put forward in this article started from the distribution principle of burden of criminal proof and based on the various problems in the practice.

\section{DistRIBUTION PRINCIPLE OF BURDEN OF CRIMINAL PROOF}

\section{A. Concept of Burden of Criminal Proof}

A person bearing the burden of proof in a criminal action also bears certain litigation risk. The accusing party needs to collect or afford relevant proof to prove the fact of the case and the claim. Otherwise, the accusing party must face the risk that the claim is not supported. The connotation of the burden of proof in China includes the burden of affording proof and the burden of persuasion. The former means both subjects of litigation afford relevant proofs for the claims they support or object to with the proceeding of the litigation; the latter the person affording the proof shall apply the proof to the case for argumentation in order to make the judge form an inner confirmation.

\section{B. Value Requirement}

The intrinsic value of distribution of burden of criminal proof is fairness and justice. Fairness and justice becomes more and more valued in modern judicial concept. Because the defendant is possible to bear criminal penalty in a criminal action, the value pursuit of fairness and justice becomes important especially. In view of juridical practice, the accusing party is the acting subject of national public power, so the defendant is difficult to combat with him. In the aspect of obtaining proof and cross-examination, firstly, the defendant is difficult to obtain the effective proof to prove his innocence and to obtain proof is still subject to many restrictions; secondly, as the acting subject of state power, the proof afforded is more credible and is easier to be confirmed by neutral judicator in his heart. Therefore, we shall consider the unequal status of both subjects fully when distributing the burden of proof, and shall insist on giving the burden of proving the prosecuted party's guilt to the accusation subject. Meanwhile, we shall not exclude the situation that the prosecuted party shall bear certain burden of proof of for some circumstance. The purpose is to narrow the distance between the accusing party and the defendant and form an equal confrontation between the two parties, which will be more advantageous for the judicator to understand the truth of the case.

The extrinsic value of distribution of burden of criminal proof is to punish criminals. The ultimate value and purposes of criminal actions are to restore the truth of the case, guarantee the rights of the injured party, let criminals get their due punishment, and free the innocent persons from the prison. Disagreements on relevant facts often occur in litigations. When it is difficult to make a decision, we shall confirm the respective adverse result of the litigation through adjusting the burden of criminal proof of both parties in order to realize the extrinsic value distribution of burden of proof and avoid the situation that innocent persons are wronged and criminals escape from punishment.

\section{Distribution Principle of Burden of Criminal Proof}

The principle of burden of proof borne by claimant. It is undoubted that the burden of proof that whether the criminal fact happens, whether the defendant is guilty and the crime severity in a criminal action shall be distributed to the accusing party. It is stipulated in article 49 of the Criminal Procedure Law that, "the burden of proof to prove the defendant's guilt in a case of public prosecution shall be borne by the people's 
procuratorate, and the burden of proof to prove the defendant's guilt in a case of private prosecution shall be borne by the private prosecutor." It is an express term for the principle of burden of proof borne by claimant, but it doesn't mean that the defendant doesn't have to bear the burden of proof. We can know from above that the connotation of the burden of proof in China includes two aspects and one is that the defendant needs not bear the burden of proof for his innocence. The defendant is a special subject, who doesn't bear the whole burden of proof, and only bear the burden of affording proof for the procedural claims and other favorable claims himself. Of course, the features of a criminal action also decide that it is impossible to follow the principle of burden of proof borne by claimant simply for the distribution of burden of proof. In a criminal action, there are many fact objects that must be proved, and the accusing party must bear the burden of proof of substantive facts, but the law doesn't stipulate that which party shall bear the burden of proof of sentencing facts and some procedural matters. At this moment, we shall observe the principle of burden of proof borne by claimant and distribute the burden of proof reasonably combined with the contents of judicial notice, presumption and standard of proof in order to realize the value of distribution of burden of proof.

The principle of litigation efficiency. "If the justice is highest value of litigation, the benefit may be deemed as the second value of litigation." [1] The contradiction between the complexity and frequency of criminal case and the limitation of judicial resources is a ubiquitous problem in all countries. Therefore, we shall consider the litigation efficiency when distributing the burden of proof and the party who has the ability and is easy to bear the burden of proof shall bear part of burden of proof so as to shorten the time of affording proof and improve litigation efficiency. We shall distribute the proof resources dynamically and allocate the burden proof reasonably between the accusing party and the defendant so that one party needs not bear too heavy burden of proof and in order to realize same litigation outcome with less litigation resources. Whether from legal level or applied level, under the premise of insisting on that the accusing party shall bear the burden of proof of the basic information of the case, if the defendant is responsible for affording relevant proof to prove some facts advantageous to the defendant, the defendant's rights will not be infringed, and it is more helpful to restore the truth of the case. It is important to distribute the burden of proof reasonably to improve litigation efficiency, but we cannot focus on the efficiency only and neglect the truth of the case.

The principle of presumption of innocence. "A person cannot be called criminal before judgment. The society cannot cancel the public protection for him or her as long as it is not clear that he or she has infringed the contract of public protection given to him or her." [2] That means as long as the prosecuted party is not judged by the court ultimately, the person shall not be deemed as a criminal. This principle also applies to the distribution of burden of criminal proof as the basic principle of criminal actions.

This principle defines the burden of proof to prove the criminal fact of the prosecuted party shall be borne by the accusation subject, and the accusing party shall perform full burden of proof, including affording relevant proof and persuasive argumentation. The accusation subject exercises national public power on behalf of the country, so it has the incomparable advantages on affording proof and argumentation. We shall follow the principle of efficiency when distributing the burden of proof. It is reasonable that accusation subject shall bear the burden of proof to prove the criminal fact of the prosecuted party. In view of general establishment of the idea of human right, the principle of presumption of innocence has been widely accepted in the world and many relevant principles have been derived, including the principle in favor of the defendant, the principle of no punishment in doubtful cases and so on, which defines that the accusing party must exclude all reasonable doubts to perform the burden of proof. In view of the seriousness of the consequences of criminal actions, if the accusing party cannot exclude all reasonable doubts of the defendant's innocence, the defendant shall not be deemed guilty, and it shall bear the adverse results of failing proof. Finally, the principle defines that the prosecuted subject shall not bear the burden of proof to prove own guilt.

The defendant shall always be deemed to have no accusation before any proof to prove his criminal fact is proved and adopted. Additionally, it is difficult to be actually equal with the accusing party for the defendant. Therefore, when a dispute appears and the accusing party cannot prove it, "in a word, the origin of litigation is started from the defendant's innocence, the balance of proof will tilt to the side of defendant at first, and the public prosecutor is responsible for putting the weights one by one to prove the defendant's guilt on the side disadvantageous to the defendant, until the balance tilt to the side of defendant's guilt completely with conviction standard according to legal requirements." [3]

The principle of objection of forcing self-incrimination. The idea of human rights protection is reflected in the principle of objection of forcing self-incrimination in modern criminal justice, its efficacy runs through the whole process of the criminal action, and it is also the most basic right held by the defendant in a criminal accusation.

In modern idea of litigation, with the principle of presumption of innocence, it guarantees that the accusation organ bears the burden of proof of the prosecuted party's criminal fact and prevents the accusation organ from transferring the burden of proof that it shall bear to the defendant in order to increase the defendant's risk of failure. This principle has following functions on the distribution of burden of proof:

Firstly, the principle can guarantee the implementation of the presumption of innocence and adjust the burden of proof borne by both subjects reasonably. Secondly, the principle can consolidate the defendant's position as a litigation subject, which is helpful to realize equal status of the accusing party and the defendant. Thirdly, the principle will increase the defendant's defending strength on the procedure to narrow the distance between the accusing party and the defendant and form an equal confrontation between the two parties. 


\section{THE CURRENT SitUATION OF DistRIBUtion OF BURDEN OF CRIMINAL PROOF IN CHINA}

\section{A. The Defects of Distribution of Burden of Criminal Proof in Current Judicial System}

The excessively simple standard of burden of proof is bad for the prosecuted party to perform the burden of affording proof. Both parties of the litigation, the investigation organ for conclusion of investigation, and the procuratorial organ review and prosecution, all above shall observe the standard of proof that "the fact of the case has been fully proved with real and sufficient proof." The purpose to make the standard is to limit the judge's discretion and ensure the realization of substantive justice. However, the stipulation is always idealized, and it is very difficult to realize it in practice. Judicial officials use their discretion to judge the fact claims subjectively so that the standards in different regions are difficult to be unified. Moreover, the standard is applied in the conclusion of investigation, review and prosecution and judgment at the same time, which shows that the standard of proof is simple and increases the burden of the defendant unreasonably. "It is most impossible to persuade the judge to believe the defendant's claim with a same standard no matter what the defendant says, and besides, the accusing party conducts the prosecution in the situation that "the fact of the case has been fully proved with real and sufficient p roof'. [4]

The private prosecutor is difficult to perform the burden of proof. It is stipulated in the Criminal Procedure Law in China that the private prosecutor shall bear the burden of proof of the defendant's guilt. Generally, the private prosecutor will report the case to the public security and judicial organs as a victim at first in reality, but the law allocates the burden of proof to the victim at this moment. The private prosecutor often lacks the ability to collect proofs as a common citizen, and he or she is difficult to judge the ability of proofs, which will causes his or her legal rights and interests to be difficult to be guaranteed.

\section{B. Lack of Clear Theoretical Standard}

The connotation of the burden of proof is defined much. The mainstream view in Chinese theoretical cycle is that its connotation includes the burden of affording proof and the burden of persuasion. As the core content of promoting the development of judicial proceedings, it cannot be distributed away from the substantial law. However, at present, the setting of concrete accusation is not considered fully into the distribution of burden of proof for criminal actions, so the theoretical system is not perfect. In addition, in practice, because it is stipulated that the accusing party shall bear the burden of proof of the defendant's guilt, we have excluded the prosecuted party from the subjects of burden of proof wrongly, which exactly shows that we have neglected the defendant's burden of proof good for his own claim and is bad to find out the truth of the case.

\section{The Dilemma of Distribution of Burden of Criminal Proof in Juridical Practice}

We pay attention to litigation efficiency excessively. The conflict between limited judicial resources and numerous criminal cases is unavoidable in the juridical practice of all countries. "We cannot ignore the cost when discussing the functions of judgment. Maybe it is the state's mission to realize disputes, so we must be regardless of the cost. However, as a practical problem, the judgment with high cost is not permitted compared to its social task with urgency and priority." [5] Therefore, because the accusation organ has congenital priority to collect proofs in practice, it is understandable to distribute the burden of proof of substantive facts to the accusing party in order to save litigation cost and improve litigation efficiency. However, corresponding supervision is lacked for the accusation subject in practice and it often performs its burden of proof negatively, which damages the benefit of the prosecuted party to a certain extent.

On the other hand, while the accusing party is bearing the burden of proof, as along as the defendant provides some information timely to make some reasonable doubts, the whole judicial proceedings will be caught in a vicious circle of "the defendant's plea -- the prosecution's verification", which will cause the waste of judicial resources. Moreover, this move will cause the real criminal offenders to fail to get corresponding punishment, and even more part of criminal offenders escape from the punishment because the current system stipulates that the accusation subject shall bear the adverse result when it is difficult to make a decision on the divergence, and the victims cannot claim the justice.

There is a deviation in the implementation of policy "leniency to those who confess, and severity to those who resist". It is stipulated in the Criminal Procedure Law that the criminal suspects or defendants shall answer the investigators' questions truthfully in the investigation, review and prosecution and other links with the criminal policy "leniency to those who confess, and severity to those who resist". Its purpose is to encourage the parties to confess their guilt according to the principle of honesty and trustworthiness and seeking truth from facts. However, to extort confessions by torture often occurs in practice. Secondly, if the prosecuted party doesn't confess, he or she will be punished severely frequently when he or she is sentenced. In accordance with the principle of objection of forcing self-incrimination in the basic principles of distribution of burden of proof in criminal actions, the prosecuted party shall not bear the burden of proof of his own guilt. However, the implementation of the policy in practice violates the above principle, which causes the defendant to bear certain burden of proof of his own guilt.

The defendant's ability to afford proof is limited. Different from the situation that the both parties in a civil action are equal, the defendant in a criminal case is always to be equal to the accusing party who exercises the public power on behalf of the state because of its specificity. Firstly, because the personal freedom of the defendant is limited at the beginning, the defendant's proof ability is weakened. Even if the defendant is not detained, his ability to collect proofs is low, so he only authorizes a lawyer and applies for legal aid to improve his own ability to afford proof. However, the defendant is still unable to implement his burden of proof because of high counsel fee and limited legal aid recourse. Secondly, lawyers' right of investigation and proof collection is limited much in practice: on one hand, lawyers' intervention time is limited strictly and they cannot collect strong proofs as soon as 
possible; on the other hand, they are impeded much by public prosecution organs when exercising the meeting right and the right to read documents in practice.

\section{RECOMMENDATIONS FOR IMPROVING THE DISTRIBUTION OF BURDEN OF CRIMINAL PROOF}

\section{A. Establish A Scientific and Perfect the Distribution Idea of Burden of Proof}

"Criminal proceedings identity cases with certain constitutive requirement as guiding image at the beginning, form the heart proffer with its substance step by step, and finally achieve the objective with assured affirmation with the fact according with certain constitutive requirement." [6] A criminal action includes the affirmation of the fact of the case according to substantial law and the proceedings of litigation according to the procedural law. Therefore, we shall fully consider the constitution of a crime to a concrete accusation when distributing the burden of proof. Referring to the practice of other countries, the accusing party only needs to prove the fact conforming to the crime entity in the Anglo-American law system. "There is no need to prove that every defendant' behavior is not justifiable defense, nor urgent danger prevention, without legal authorization." [7] The defendant only needs to afford the proof good for himself to overturn the claim of the accusing party. The current theory of constitution of a crime in China is developed and formed based on the relevant theory of former Soviet Union, which is different from the Anglo-American law system in the classification method. In order to prove the existence of a basic fact consistent with constitution of a crime, firstly we need to consider whether the act is illegal and accountable, because illegality and accountability cannot be separated. If we copy the foreign theory system completely, it will not be applicable in our country, so we shall adjust it and change the current solid-state crime theory system. Therefore, we shall improve the criminal legislation technology in our country, pay attention to inherent unity of substantial law and procedural law, stipulate the system of the distribution of burden of proof in the Criminal Procedure Law in detail, and summarize the laws of various forms of distribution in criminal substantive law. For the substantial law, we shall be fully aware of the relevant principles of the procedural law, ensure that the distribution of the burden of proof for each accusation accords with the basic law, distribute the burden of necessary to the prosecuted party, and fully guarantee the ability to fulfill his burden, so as to find out the truth of the case.

\section{B. Enhance the Defendant's Ability to Bear the Burden of Proof}

We can know from the above that the defendant needs to bear the burden of proof of some specific fact, so the defendant's ability to perform relevant burden shall be enhanced, but the prosecuted party's litigation risk caused by this shall not be increased. In addition, because of lack of cognition and other reasons, the defendant's performance of specific burden of proof is not guaranteed so that it is difficult to equal to the accusing party. Therefore, it shall be improved from the following aspects:
Perfect the lawyers' right of investigation and proof collection. Investigation stage is an important link in a criminal action. At present, the law allows lawyers to intervene in the investigation stage, but the legal services in this stage for lawyers are less, which will result in the failure of lawyers to participate in the whole process of criminal actions factually. The law shall allow lawyers to exercise the right to read documents and meeting right in the investigation stage, and the investigation organ shall not disturb or hinder without reasons. Meanwhile, the law shall allow lawyers to accompany the parties to take interrogations because the prosecuted parties often lack the legal awareness to protect their own rights and interests. Secondly, as a state organ, the investigation organ shall provide certain convenience for the parties who need the help of legal professionals. Lawyers shall not be impeded by investigations and inspection organs when they provide professional services, and they shall be guaranteed to have enough time and space to exercise relevant rights. Moreover, relevant measures shall be taken to guarantee the defendants' right of investigation and proof collection. We can establish an appeal system for the situation that the defendants are not permitted to obtain proofs, and enlarge the time range for the defendants to apply for obtaining proofs, including all requirements according with relevant stipulations before judgment and during the judgment process.

Perfect the legal compulsory defense system. Because there are too less compulsory defense situations in current law, in order to enhance the proof ability of the defendant, we can enlarge the application range of legal aid system and diversify the obtain ways of legal aid. The defendants meeting the conditions can apply by themselves and their application shall be admitted. Secondly, the situation that the defendants only can defend themselves in litigation because they have economic problems to be difficult to pay counsel fees or other reasons shall be brought into the scope of compulsory defense. Finally, the application range of legal aid system shall be expanded to all stages of criminal proceedings, not only limited to the judgment stage. On the other hand, the rewards of the lawyers designated for legal aid shall be increased in order to avoid the situation that lawyers are not active.

Guarantee the defendants' full participation right. The prosecuted party is always in a weak position compared to the prosecution organ. The defendants often are limited with corresponding coercive measures so that their degree of participation in criminal actions is low and they obtain information relatively late, so the defendants cannot afford the proofs good for them in time even if they have. Therefore, it is necessary to improve the prosecuted party's degree of participation in litigation.

The evidence materials submitted to procurators and the facts proved by them shall be clear, and the evidence materials provided shall be submitted to defense lawyers for reference in time according to relevant procedure. It is forbidden to take the malignant measure of "sudden proof strike". We shall guarantee the defenders have enough time and space to prepare relevant defense materials in order to realize real confrontation.

The law shall give the right to read documents to the defendants and their defense lawyers and stipulate that they can 
look up, extract and copy the materials related to cases. However, they often are limited much to look up material in practice. We shall observe the principle of "freedom means no prohibition by law" strictly on the range that the defendants can look up materials. Unless it is stipulated expressly that the details that cannot be known by the defendants are not necessary to be publicized, they shall not be limited.

\section{Implement Relevant Criminal Policy}

This principle is often misunderstood in practice and people think the leniency to those who confess means to induce the parties and the severity to those who resist means to coerce the parties. In fact, the root of the problem is not policies, but the deviation in the implementation process. It is different from the problem of the burden of proof. No matter what the criminal suspects or the defendants state, they only can conduct argumentation with legal and effective proofs as prosecution subjects so as to confirm that whether exist relevant criminal facts and circumstances that will influence the crime severity. Therefore, it is not necessary to abandon this policy. On the contrary, we shall try to keep it and completely eradicate relevant nonstandard behaviors.

\section{REFERENCES}

[1] [America] E. Bodenheimer Jurisprudence --- Philosophy of Law and Methods [M]. translated by Deng Zhenglai, Beijing: Huaxia Publishing House, 987.104.

[2] [Italy] Beccaria, On Crimes and Punishment [M]. translated by Huang Feng, Beijing: Encyclopedia of China Publishing House, 1996.57.

[3] Bian Jianlin, Modernization of Criminal Action [M]. Beijing: China Legal Publishing House, 2003.162.

[4] Huang Yong, Allocation of Burden of Proof in Criminal Justice [M]. Beijing: Publishing House of People's Public Security University of China, 2005.195.

[5] [Japan] Tanase Takashio, Dispute Resolution and Judgment System, [M] translated by Wang Yaxin, Beijing: China University of Political science and Law Press, 2004.267.

[6] [Japan] Ono Shinichiro, Theory of Constitutive Elements of Crime [M]. translated by Wang Tai, Beijing: Publishing House of People's Public Security University of China, 1987.137.

[7] Liu Chunshan, Bi Yuqian, Zheng Xu, Research on the Rule of Evidence in Litigation [M]. Beijing: China Legal Publishing House, 2000.280. 